\title{
Studi performa Domba Sapudi pada berbagai umur di UPT Pembibitan Ternak dan Hijauan Makanan Ternak Jember - Jawa Timur
}

\section{Study on the performance of Sapudi Sheep on various ages at UPT Pembibitan Ternak dan Hijauan Makanan Ternak Jember - East Java}

\author{
Luqman Bimo Aji, Erfan Kustiawan, Suci Wulandari, dan Niswatin \\ Hasanah \\ Program Studi Produksi Ternak, Jurusan Peternakan, Politeknik Negeri Jember, \\ Jl. Mastrip No.164, Krajan Timur, Sumbersari, Kec. Sumbersari, Kabupaten \\ Jember, Jawa Timur. 68121 \\ *Email Koresponden: luqmanbimo9@gmail.com
}

\begin{abstract}
Abstrak. Tujuan dari kajian ini adalah untuk mengetahui bagaimanakah performa domba sapudi pada berbagai fase umur dan domba sapudi pada fase umur berapakah yang memiliki performa dan efisiensi pakan terbaik. Studi ini dilaksanakan di UPT Produksi Ternak dan Hijauan Makanan Ternak Jember pada tanggal 15 Agustus 2020 - 10 September 2020. Bahan yang digunakan dalam studi ini adalah domba sapudi betina dengan tiga (3) fase umur yakni, umur 3 - 6 bulan dengan rerata bobot badan sebesar 13,36 kg; 6 - 12 bulan dengan rerata bobot badan 16,68 kg; dan $>12$ bulan dengan rerata bobot badan 19,58 $\mathrm{kg}$. Masing - masing fase umur terdiri dari 10 ekor domba. Data disajikan dalam bentuk tabel yang dijabarkan secara deskriptif. Parameter yang diamati adalah konsumsi pakan, pertambahan bobot badan harian, nilai konversi pakan, dan income over feed cost sebagai tolak ukur efisiensi pakan. Performa domba Sapudi dan efisiensi pakan terbaik dihasilkan pada fase umur $>12$ bulan, yaitu PBBH sebesar 55,71 g/ekor/hari, dan rerata konversi pakan 10,42 dengan menghasilkan IOFC sebesar Rp1.400.
\end{abstract}

Kata kunci: Domba Sapudi, Efisiensi Pakan, Jember, Performa Produksi.

Abstract. The aims of this study were to find out how the performance of Sapudi sheep on various age phases and the Sapudi sheep on what age phase had the best performance and feed efficiency. This study was carried out at UPT Produksi Ternak dan Hijauan Makanan Ternak Jember on August 15, 2020 - September 10, 2020. The materials used were female Sapudi sheep with three (3) age phases, namely, 3 - 6 months of age with an average body weight of 13, 36 kg; 6 - 12 months with an average body weight of $16.68 \mathrm{~kg}$; and $>12$ months with an average body weight of $19.58 \mathrm{~kg}$. Each age phase was 10 sheeps. Data were presented and described descriptively. Parameters observed were feed consumption, daily body weight gain, feed conversion value, and income over feed cost as a measure of feed efficiency. the best of Sapudi sheep performance and feed efficiency were produced at the age of >12 months old, average daily gain of $55.71 \mathrm{~g} / \mathrm{sheep} /$ day, and the average of feed conversion was 10.42, with an IOFC of Rp.1,400.

Keywords: Sapudi Sheep, Feed Efficiency, Jember, Production Performance. 
Aji et al.

ANIMPRO: Conference of Applied Animal Science Proceeding Series

\section{PENDAHULUAN}

Berdasarkan keputusan Menteri Pertanian nomor 2389/Kpts/LB.430/8/2012 domba Sapudi merupakan salah satu domba rumpun lokal yang mempunyai sebaran asli geografis di Jawa Timur yang keberadaanya perlu untuk dilestarikan. Domba Sapudi merupakan domba tipe pedaging, sehingga sangat potensial untuk dikembangkan sebagai salah satu ternak penyuplai daging nasional. Domba sapudi mempunyai ciri - ciri ukuran badan yang lebih besar dari domba lokal pada umumnya, tekstur bulu yang lebih kasar, ekor yang lebih panjang dan juga pangkal ekor yang lebih besar dengan timbunan lemak yang cukup banyak. Kemampuan beradaptasi terhadap iklim, penyakit, dan pakan berkualitas rendah cukup baik.

Domba sapudi mempunyai daya adaptasi baik terhadap iklim, penyakit, dan pakan berkualitas rendah. Domba sapudi mempunyai sumber gen yang khas, produktif dipelihara dengan biaya rendah, serta dapat beranak sepanjang tahun, serta mempunyai posisi yang sangat strategis di masyarakat karena mempunyai fungsi sosial, ekonomi, dan budaya.

Domba sapudi mempunyai ekor panjang dan besar dipenuhi dengan lemak yang berguna untuk mencukupi kebutuhan nutrisinya pada saat kekurangan makanan. Akan tetapi, dibalik manfaat ekor tersebut, besarnya ekor membuat domba Sapudi sulit untuk melakukan perkawinan. Ekor besar domba Sapudi betina biasanya akan menutupi vulva dan menyulitkan bagi domba Sapudi jantan untuk melakukan perkawinan. Dibalik potensinya sebagai penyumbang suplai daging nasional, domba lokal mempunyai kelemahan yang kurang diminati peternak, yakni rendahnya performa pertumbuhan khususnya pada pertambahan bobot badannya yang menurut Jaya, et al., (2020) rerata pertambahan bobot badan domba lokal yang dipelihara di peternakan rakyat hanya berkisar $30 \mathrm{~g} / \mathrm{hari}$. Beragamnya informasi performa domba lokal yang belum tentu tepat menunjukan performa domba Sapudi, menjadikan hal ini sangat penting untuk diketahui mengenai performa domba sapudi berbagai fase umur dalam rangka program pemeliharaan dan atau pembibitan yang akan dijalankan.

Minimnya informasi terhadap performa domba Sapudi dimungkinkan menjadi alasan peternak jarang memilih domba sapudi untuk dilakukan pemeliharaan. Rendahnya minat peternak dalam pemeliharaan domba lokal khususnya domba Sapudi ini bertentangan dengan program pemerintah untuk melakukan pelestarian terhadap plasma nutfah lokal, hal ini menjadikan didirikannya instansi pemerintah yakni UPT PT dan HMT Jember. UPT PT dan HMT Jember di bawah naungan Dinas Peternakan Provinsi Jawa Timur mempunyai tugas untuk kembali melestarikan plasma nutfah murni khususnya domba Sapudi. Studi ini layak untuk dikaji dan dilakukan mengingat masih sedikitnya informasi yang tepat mengenai performa domba sapudi pada berbagai umur sehingga, atas dasar inilah dilakukan studi tentang performa domba sapudi pada berbagai umur.

Tujuan dari kajian ini adalah untuk mengetahui bagaimanakah performa domba sapudi pada berbagai fase umur dan domba sapudi pada fase umur berapakah yang memiliki performa dan efisiensi pakan terbaik. Kajian tentang performa domba sapudi ini diharapkan menjadi bahan informasi untuk semua orang yang ingin memelihara ternak khususnya domba sapudi.

\section{MATERI DAN METODE}

Waktu dan Tempat
Studi ini dilaksanakan selama 3 Minggu pada Tanggal 15 Agustus - 6 September 2020. Studi ini dilaksanakan di UPT PT dan HMT Jember, Desa Curah Manis, Sidomulyo, Kecamatan Silo, Kabupaten Jember, Jawa Timur.

\section{Alat dan Bahan}

Peralatan yang digunakan dalam mendukung studi ini, antara lain: sekop, sapu lidi, gerobak, timbangan gantung digital, sabit, tempat pakan, tempat minum, selang, dan alat tulis. Bahan yang digunakan dalam studi ini adalah domba Sapudi betina dengan tiga (3) fase umur yakni, umur 3 6 bulan dengan rerata bobot badan sebesar 13,36 kg; 6 - 12 bulan dengan rerata bobot badan $16,68 \mathrm{~kg}$; dan > 12 bulan dengan rerata bobot badan 19,58 kg. Masing - masing fase umur tersebut menggunakan 10 ekor domba betina. 
Aji et al.

ANIMPRO: Conference of Applied Animal Science Proceeding Series

\section{Metode Penelitian}

Metode yang dilakukan dalam studi ini adalah mengumpulkan data primer yaitu dengan ikut dalam pemeliharaan dan pemberian pakan, serta melakukan penimbangan bobot domba sampel pada bulan Agustus - September. Data sekunder diperoleh dengan cara menyalin pencatatan tentang data pakan yang diberikan, komposisi konsentrat, serta alur pemeliharaan domba sapudi.

Teknik pengambilan sampel dalam studi ini menggunakan metode pengambilan sampel acak terstratifikasi. Metode pengambilan sampel acak terstratifikasi adalah metode pemilihan sampel dengan cara membagi populasi ke dalam kelompok yang homogen yang disebut strata, dan kemudian sampel diambil secara acak dari tiap strata tersebut (Nurhayati, 2008). Data yang diperoleh untuk selanjutnya diolah dan ditabulasikan, kemudian disajikan dalam bentuk tabel yang dijabarkan secara deskriptif.

\section{Konsumsi Pakan Segar}

\section{Parameter Pengamatan}

Konsumsi pakan merupakan selisih dari jumlah pakan yang diberikan dengan jumlah sisa pakan (Nuningtyas, 2014). Pengumpulan sisa pakan dilakukan setiap hari pada pagi hari sebelum pakan sisa dibersihkan, untuk selanjutnya dihitung rerata konsumsi pakan pada setiap ekornya, dan kemudian dikonversikan ke dalam bentuk BK.

\section{Pertambahan Bobot Badan Harian (PBBH)}

Pertambahan bobot badan Harian (PBBH) merupakan selisih antara bobot badan akhir dengan bobot badan awal dibagi dengan banyaknya hari (Nuningtyas, 2014). Rumus untuk Menghitung PBBH adalah:

$$
\text { PBBH }(\mathrm{kg} / \text { ekor })=\text { BB akhir }- \text { BB awal } / \text { Banyaknya Hari. }
$$

\section{Konversi Pakan dalam Bahan Kering (BK)}

Konversi ransum atau feed convertion ratio (FCR) didapat dari membagi jumlah pakan bahan kering yang dikonsumsi dengan PBBH dengan satuan berat yang sama. Konversi pakan merupakan perbandingan antara konsumsi pakan dengan pertambahan bobot badan. Konversi pakan dihitung secara matematis dengan rumus sebagai berikut:

$$
\mathrm{FCR}=\frac{\text { konsumsi pakan } \mathrm{BK}(\mathrm{kg})}{\text { Pertambahan bobot badan Harian }(\mathrm{kg})}
$$

\section{Income Over Feed Cost (IOFC)}

Perhitungan Income Over Feed Cost (IOFC) atau pendapatan atas biaya pakan dilakukan untuk mengetahui nilai ekonomis pakan terhadap pendapatan di UPT PT dan HMT Jember. Income over feed cost dihitung dengan cara mengalikan rerata PBBH dengan harga jual domba, yaitu Rp37.000,00/kg bobot hidup (asumsi bulan Agustus 2021) kemudian mengurangi pendapatan dari penjualan tersebut dengan biaya yang dikeluarkan untuk pakan (Rp/ekor).

\section{HASIL DAN PEMBAHASAN}

\section{Konsumsi Pakan}

Pakan yang diberikan di UPT PT dan HMT Jember menggunakan 2 jenis pakan, yakni hijauan dan konsentrat. Hijauan yang diberikan berupa rumput gajah segar sebanyak $10 \%$ dari berat badan, sementara untuk konsentrat segar sebanyak $2 \%$ dari berat badan domba tersebut. Setelah dilakukan perhitungan, maka domba fase umur 3 - 6 bulan mengkonsumsi pakan total dengan rerata $1,45 \mathrm{~kg} / \mathrm{ekor} / \mathrm{hari}$, domba fase umur 6 - 12 bulan mengkonsumsi pakan dengan rerata $1,94 \mathrm{~kg} / \mathrm{ekor} / \mathrm{hari}$, dan domba pada fase umur $>12$ bulan mengkonsumsi pakan dengan rerata $2,28 \mathrm{~kg} / \mathrm{ekor} / \mathrm{hari}$ (Tabel 1 ). 
Aji et al.

ANIMPRO: Conference of Applied Animal Science Proceeding Series

Tabel 1. Rerata Konsumsi Pakan Segar

\begin{tabular}{|c|c|c|c|c|c|c|c|c|c|c|}
\hline \multirow[t]{2}{*}{$\begin{array}{l}\text { Fase } \\
\text { Umur } \\
\text { (Bulan) }\end{array}$} & \multicolumn{3}{|c|}{$\begin{array}{c}\text { Pemberian Pakan } \\
\text { (kg/ekor/hari) } \\
\text { Minggu ke- }\end{array}$} & \multicolumn{3}{|c|}{$\begin{array}{c}\text { Sisa Pakan } \\
\text { (kg/ekor/hari) } \\
\text { Minggu ke- }\end{array}$} & \multicolumn{3}{|c|}{$\begin{array}{c}\frac{\text { Konsumsi }}{(\mathrm{kg} / \mathrm{ekor} / \mathrm{hari})} \\
\text { Minggu ke- }\end{array}$} & \multirow[t]{2}{*}{$\begin{array}{c}\text { Rerata } \\
\text { Konsumsi } \\
\text { (kg/ekor/hari) }\end{array}$} \\
\hline & 1 & 2 & 3 & 1 & 2 & 3 & 1 & 2 & 3 & \\
\hline $3-6$ & 1,61 & 1,61 & 1,61 & 0,13 & 0,16 & 0,19 & 1,48 & 1,45 & 1,42 & 1,45 \\
\hline $6-12$ & 2,00 & 2,00 & 2,00 & 0,06 & 0,07 & 0,06 & 1,94 & 1,93 & 1,94 & 1,94 \\
\hline$>12$ & 2,36 & 2,36 & 2,36 & 0,09 & 0,08 & 0,07 & 2,27 & 2,28 & 2,29 & 2,28 \\
\hline
\end{tabular}

Sumber: Data primer (2020)

Sisa pakan terbanyak dihasilkan oleh domba Sapudi pada fase umur 3 - 6 bulan dengan rerata fluktuasi pakan terbesar dihasilkan pada minggu ke- 3 dengan jumlah $0,19 \mathrm{~kg}$ dan terkecil pada minggu ke- 1 berjumlah $0,13 \mathrm{~kg}$, hal ini disebabkan oleh batang hijauan yang masih terlalu panjang untuk dikonsumsi ternak dan konsentrat yang masih belum tercampur secara homogen. Sementara itu, rerata sisa pakan pada domba fase umur 6 - 12 bulan serta domba fase umur > 12 bulan sedikit lebih kecil jika dibandingkan dengan domba pada fase umur 3 - 6 bulan, hal ini disebabkan domba pada kedua fase tersebut masih bisa mengkonsumsi batang hijauan yang terlalu panjang.

Konsumsi pakan yang telah disebutkan di atas masih dalam bentuk segar, perlu adanya konversi konsumsi pakan dari bentuk segar ke bahan kering (Tabel 1), hal ini bertujuan guna meminimalisir bias perhitungan dikarenakan kandungan air pada bahan segar yang masih sangat tinggi.

Tabel 2. Rerata Konsumsi Bahan Kering

\begin{tabular}{cccc}
\hline Rerata Konsumsi BK (kg/ekor/hari) & $3-6$ bulan & $6-12$ Bulan & $>12$ Bulan \\
\hline Hijauan & 0,215 & 0,285 & 0,334 \\
Konsentrat & 0,129 & 0,182 & 0,217 \\
\hline Jumlah & 0,344 & 0,467 & 0,551 \\
\hline
\end{tabular}

Sumber: Data primer (2020)

Hasil rerata konsumsi bahan kering dalam penelitian ini masih sedikit lebih kecil daripada standar rerata kebutuhan konsumsi bahan kering domba betina sistem pembibitan yang secara lengkap dijabarkan pada Tabel 3. Kebutuhan konsumsi pakan yang kurang, bisa menyebabkan ternak domba mengalami penurunan laju pertumbuhan serta penambahan bobot badan yang tidak sesuai dengan targetnya.

Tabel 3. Standar Rerata Kebutuhan Konsumsi BK Domba Lepas Sapih

\begin{tabular}{ccccc}
\hline $\begin{array}{c}* \text { Berat Badan } \\
(\mathrm{kg})\end{array}$ & $\begin{array}{c}{ }^{*} \mathrm{BK} \\
(\% \mathrm{BB})\end{array}$ & $\begin{array}{c}* * 3-6 \text { Bulan } \\
(\mathrm{kg} / \text { ekor/hari })\end{array}$ & $\begin{array}{c}* * 6-12 \text { Bulan } \\
(\mathrm{kg} / \text { ekor/hari })\end{array}$ & $\begin{array}{c}* * \text { 12 Bulan } \\
(\mathrm{kg} / \mathrm{ekor} / \mathrm{hari})\end{array}$ \\
\hline 5 & 4,0 & & & \\
10 & 3,3 & $0,401-0,534$ & $0,500-0,667$ & $0,587-0,783$ \\
20 & 3,3 & & & \\
30 & 3,3 & & &
\end{tabular}


Aji et al.

ANIMPRO: Conference of Applied Animal Science Proceeding Series

\begin{tabular}{ll}
40 & 3,0 \\
\hline Kisaran & $3,0-4,0$ \\
\hline Ket: & ${ }^{*}$ Standar kebutuhan konsumsi BK domba lepas sapih (Kementan, 2014). \\
& ${ }^{* *}$ Hasil Perhitungan rerata kebutuhan konsumsi BK berdasarkan bobot badan. \\
& Sumber: ${ }^{*}$ Permentan (2014), ${ }^{* *}$ Data Primer (2020)
\end{tabular}

\section{PBBH Domba Sapudi Berbagai Umur}

Pengukuran bobot badan menjadi salah satu kriteria yang digunakan untuk mengukur pertumbuhan. Pertambahan bobot badan didefinisikan sebagai kemampuan ternak untuk mengubah nutrisi yang terdapat dalam pakan menjadi daging. Pertambahan bobot badan sering menjadi salah satu acuan untuk menilai kualitas bahan pakan ternak dan kuantitas pemberian pakan untuk ternak tersebut. Pertambahan bobot badan ternak dapat diamati dengan menghitung selisih bobot badan akhir dengan bobot badan awal (Tabel 4)

Hasil pengamatan dan perhitungan PBBH selama 3 minggu, diketahui bahwa domba sapudi pada fase umur 3 - 6 bulan pada tabel di atas mempunyai rerata $\mathrm{PBBH}$ sebesar 27,62 g/ekor/hari. Hasil tersebut terbilang masih terlalu rendah apabila dibandingkan dengan penelitian yang dilakukan oleh Metkono, et al., (2011) yang menggunakan domba lokal betina di Kabupaten Bogor dengan umur 6 bulan dengan bobot awal berkisar antara 14 - $18 \mathrm{~kg}$ menghasilkan PBBH berkisar antara 36 - 73 g/ekor/hari.

Tabel 4. PBBH Domba Sapudi Fase Umur 3 - 6 Bulan

\begin{tabular}{ccccc}
\hline $\begin{array}{c}\text { No. Tatto } \\
\text { Domba }\end{array}$ & $\begin{array}{c}\text { Bobot Badan } \\
\text { Awal } \\
(\mathrm{kg})\end{array}$ & $\begin{array}{c}\text { Bobot Badan } \\
\text { Akhir 3 Minggu } \\
(\mathrm{kg})\end{array}$ & $\begin{array}{c}\text { Total PBB } \\
(\mathrm{kg})\end{array}$ & $\begin{array}{c}\text { PBBH } \\
(\mathrm{g} / \mathrm{ekor} / \mathrm{hari})\end{array}$ \\
\hline 658 & 13,9 & 14,5 & 0,6 & 28,57 \\
346 & 12,8 & 13,3 & 0,5 & 23,81 \\
518 & 12,7 & 13,3 & 0,6 & 28,57 \\
631 & 14,3 & 15,1 & 0,8 & 38,1 \\
608 & 12,4 & 13 & 0,6 & 28,57 \\
BN1 & 12,5 & 13,4 & 0,9 & 42,86 \\
671 & 15,3 & 15,9 & 0,6 & 28,57 \\
528 & 13,1 & 13,6 & 0,5 & 23,81 \\
BN2 & 12,6 & 13 & 0,4 & 19,05 \\
589 & 14 & 14,3 & 0,3 & 14,29 \\
\hline \multicolumn{5}{c}{ Rerata PBBH Domba Sapudi Sampel (g/hari) } \\
\hline
\end{tabular}

Sumber: Data primer (2020)

Rendahnya PBBH yang didapat oleh domba sapudi fase umur 3 - 6 bulan pada kajian ini disebabkan oleh rendahnya pakan yang dikonsumsi ternak tersebut yang didukung oleh pendapat Suwignyo, et al., (2016) yang menyatakan bahwa pertambahan bobot badan ternak ruminansia sangat dipengaruhi oleh kualitas dan kuantitas pakan, maksudnya adalah penilaian PBB ternak sebanding dengan ransum yang dikonsumsinya. PBBH yang rendah juga bisa disebabkan oleh kualitas ransum yang dikonsumsi masih rendah. Faktor umur juga menjadi sebab PBBH yang dihasilkan rendah, karena pada fase umur 3 - 6 bulan pertumbuhan domba masih berfokus pada pertumbuhan tulang dan organ dalam.

Standar kebutuhan pakan harus digunakan sebagai acuan kebutuhan ternak disesuaikan dengan kondisi ternak. Penggunaan bahan pakan yang murah dan kandungan nutrisi yang dapat memenuhi kebutuhan ternak dalam menyusun ransum akan sangat menguntungkan bagi peternak (Sampurna, 2016). 
Aji et al.

ANIMPRO: Conference of Applied Animal Science Proceeding Series

Tabel 5. Formulasi dan Nutrisi Ransum

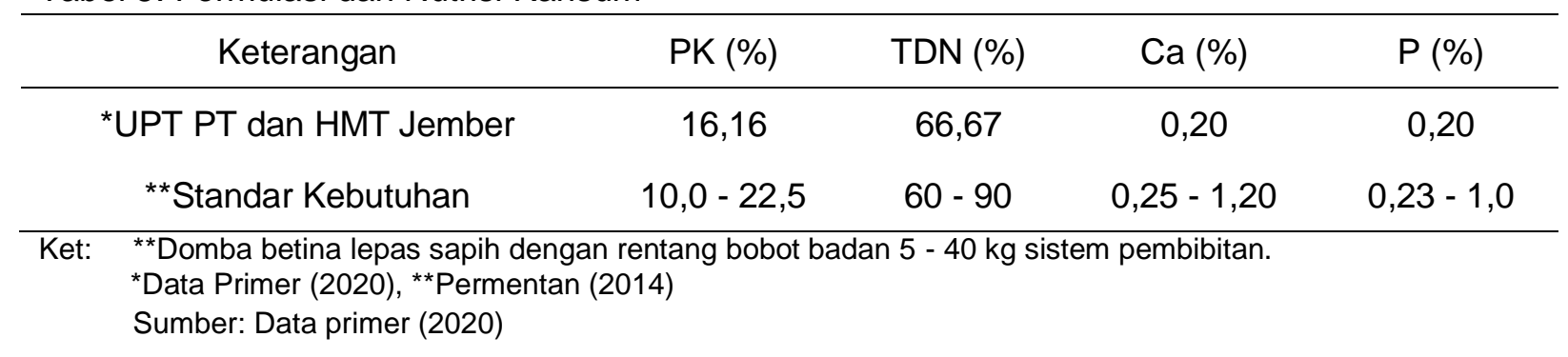

Formulasi ransum yang digunakan di UPT PT dan HMT Jember sudah cukup sesuai apabila dibandingkan dengan standar rerata kebutuhan nutrisi domba betina lepas sapih yang ditetapkan oleh Menteri Pertanian Republik Indonesia. Akan tetapi, apabila PBBH yang dicapai masih dirasa kurang tinggi, maka perlu adanya peningkatan baik dari tingkat konsumsi pakan dan nutrisi dari ransum itu sendiri. Menurut Setiadi, et al., (2016) bahwa PBB ternak khususnya ruminansia sangat dipengaruhi oleh kualitas pakan.

Tabel 6 menjelaskan bahwa PBBH domba sapudi pada fase umur 6 - 12 bulan mempunyai rerata sebesar $41,90 \mathrm{~g} / \mathrm{ekor} / \mathrm{hari}$, hasil tersebut tidak jauh berbeda dengan hasil penelitian Metkono, et al., (2011) yang menyatakan bahwa domba lokal betina di Kabupaten Bogor dengan bobot badan awal berkisar 14 - $18 \mathrm{~kg}$ menghasilkan PBBH sebesar 36 - $67 \mathrm{~g} / \mathrm{ekor} / \mathrm{hari}$, akan tetapi hasil kajian PBBH domba Sapudi fase umur 6 - 12 bulan ini masih sedikit lebih kecil daripada PBBH domba garut hasil penelitian Praja, et al., (2020) yang menyatakan bahwa domba Garut umur lepas sapih hingga umur 8 bulan mempunyai PBBH dengan rerata 45,85 g/ekor/hari.

Tabel 6. PBBH Domba Sapudi Fase Umur 6 - 12 Bulan

\begin{tabular}{ccccc}
\hline $\begin{array}{c}\text { No. Tatto } \\
\text { Domba }\end{array}$ & $\begin{array}{c}\text { Berat Badan } \\
\text { Awal } \\
(\mathrm{kg})\end{array}$ & $\begin{array}{c}\text { Bobot Badan } \\
\text { Akhir 3 Minggu } \\
(\mathrm{kg})\end{array}$ & $\begin{array}{c}\text { Total PBB } \\
(\mathrm{kg})\end{array}$ & $\begin{array}{c}\text { PBBH } \\
(\mathrm{g} / \mathrm{ekor} / \mathrm{hari})\end{array}$ \\
\hline 459 & 17,2 & 18,2 & 1,0 & 47,62 \\
007 & 18,9 & 19,5 & 0,6 & 28,57 \\
357 & 18,3 & 19 & 0,7 & 33,33 \\
584 & 16,5 & 17,5 & 1,0 & 47,62 \\
605 & 14,3 & 14,9 & 0,6 & 28,57 \\
491 & 13 & 14,3 & 1,3 & 61,90 \\
411 & 15,5 & 16,3 & 0,8 & 38,10 \\
010 & 17,7 & 18,8 & 1,1 & 52,38 \\
606 & 17,1 & 17,5 & 0,4 & 19,05 \\
585 & 18,3 & 19,6 & 1,3 & 61,90 \\
\hline \multicolumn{4}{c}{ Rerata PBBH Domba Sapudi Sampel (g/hari) } \\
\hline
\end{tabular}

Sumber: Data primer (2020)

Malewa, (2009) melaporkan bahwa perbedaan bobot badan pada makhluk hidup adalah wajar, karena bobot badan sangat dipengaruhi situasi dan kondisi lingkungan, yakni gelisah, selesai makan, terlalu banyak minum atau baru saja membuang feses.

Domba sapudi fase umur $>12$ bulan mempunyai rerata PBBH tertinggi dibandingkan dengan PBBH domba sapudi pada fase lain, yakni sebesar 55,71 g/ekor/hari (Tabel 7). Metkono, et al., (2011) menyatakan bahwa domba lokal betina di Kabupaten Bogor dengan bobot badan awal berkisar 14 - $18 \mathrm{~kg}$ menghasilkan PBBH sebesar 36 - 67 g/ekor/hari, hal ini mempunyai arti bahwa rerata PBBH pada domba sapudi betina pada kajian ini masih lebih baik daripada PBBH domba lokal jantan dari penelitian yang telah diuraikan tersebut. 
Aji et al.

ANIMPRO: Conference of Applied Animal Science Proceeding Series

Tabel 7. PBBH Domba Sapudi Fase Umur >12 Bulan

\begin{tabular}{ccccc}
\hline No. Tatto Domba & $\begin{array}{c}\text { Berat Badan } \\
\text { Awal } \\
(\mathrm{kg})\end{array}$ & $\begin{array}{c}\text { Bobot Badan } \\
\text { Akhir 3 Minggu } \\
(\mathrm{kg})\end{array}$ & $\begin{array}{c}\text { Total PBB } \\
(\mathrm{kg})\end{array}$ & $\begin{array}{c}\text { PBBH } \\
(\mathrm{g} / \text { ekor/hari) }\end{array}$ \\
\hline 545 & 20,5 & 21,6 & 1,1 & 52,38 \\
501 & 19,1 & 20,4 & 1,3 & 61,9 \\
551 & 18,2 & 19,6 & 1,4 & 66,67 \\
558 & 19,7 & 21,3 & 1,6 & 76,19 \\
335 & 20,2 & 21,5 & 1,3 & 61,9 \\
100 & 20,9 & 21,8 & 0,9 & 42,86 \\
345 & 19,3 & 20,3 & 1,0 & 47,62 \\
553 & 18 & 18,7 & 0,7 & 33,33 \\
002 & 19,4 & 20,6 & 1,2 & 57,14 \\
350 & 20,5 & 21,7 & 57,14 \\
\hline \multicolumn{4}{c}{ Rerata PBBH Domba Sapudi Sampel (g/hari) } \\
\hline
\end{tabular}

Sumber: Data primer (2020)

Hasil rerata PBBH berbagai umur di atas didapat hasil bahwa PBBH domba Sapudi fase umur $>12$ bulan mempunyai PBBH terbesar yakni dengan rerata 55,71 g/ekor/hari, dilanjutkan oleh domba sapudi fase umur 6 - 12 bulan dengan hasil rerata sebesar 41,90 g/ekor/hari, dan PBBH terkecil dihasilkan oleh domba sapudi pada fase umur 3 - 6 bulan yakni dengan rerata sebesar 27,62 g/ekor/hari. Laju pertumbuhan ternak berbentuk sigmoid yaitu terjadi peningkatan bobot badan dari lahir sampai pubertas. Kondisi ini didukung Munir \& Kardiyanto, (2015) bahwa domba akan mengalami pertumbuhan yang cepat dan akan semakin meningkat hingga pada akhirnya akan menurun pada saat domba mendekati kedewasaan tubuh. Domba akan mencapai $75 \%$ bobot dewasa pada saat umur satu tahun, dan sisanya $25 \%$ pada umur 18 bulan.

Hasil PBBH yang tidak terlalu tinggi pada ketiga fase umur di atas masih sejalan dengan tujuan pemeliharaan pada UPT PT dan HMT Jember yakni pembibitan. Bagiarta, et al., (2017) menyatakan bahwa ternak yang dipelihara untuk tujuan pembibitan tidak memerlukan kondisi tubuh yang terlalu gemuk.

\section{Konversi Pakan}

\section{Efisiensi Pakan}

Perbedaan nilai konversi ternak dipengaruhi oleh kualitas pakan, nilai kecernaan dan pemanfaatan zat gizi dalam proses metabolisme di dalam jaringan tubuh ternak. Semakin baik kualitas pakan yang dikonsumsi ternak yang diikuti oleh pertambahan bobot badan yang tinggi, maka nilai konversi pakan akan semakin rendah dan akan semakin efisien pakan yang digunakan (Rochana, et al., 2020).

Hasil perhitungan konversi pakan pada fase umur $3-6$ diperoleh hasil rerata dengan nilai 13,58 , hal ini mempunyai arti bahwa untuk menghasilkan $1 \mathrm{~kg}$ bobot badan pada domba Sapudi tersebut, akan membutuhkan sebanyak 13,58 kg pakan (Tabel 8). Braymana, et al., (2014) dalam penelitiannya menyatakan bahwa domba lokal jantan umur lepas sapih menghasilkan rerata konversi pakan dengan rentang 6,32 - 11,74. Hasil yang lebih besar yang didapat dari kajian ini dimungkinkan karena perbedaan jenis kelamin pada domba yang diteliti oleh Braymana dengan domba yang digunakan pada kajian ini. Konversi pakan yang tidak efisien pada kajian ini bisa disebabkan oleh pertambahan bobot badan yang rendah dan konsumsi pakan yang tinggi.

Hasil perhitungan konversi pakan pada fase umur 6 - 12 bulan memperoleh hasil rerata dengan nilai 12,67 (Tabel 8). Menurut Zulkarnain, et al., (2018) dalam penelitian di Desa Pangkatrejo Dusun Tuyuh Kecamatan Lamongan Kabupaten Lamongan, domba ekor gemuk (DEG) betina menghasilkan nilai konversi pakan dengan rentang 3,1 - 15,3. Penelitian lanjutan 
Aji et al.

ANIMPRO: Conference of Applied Animal Science Proceeding Series

yang dilaksanakan oleh Supratman, et al., (2016) dikatakan bahwa domba lokal jantan berumur \pm 8 bulan menghasilkan nilai FCR sebesar 7,63 - 7,82. Perbedaan yang cukup jauh ini bisa saja disebabkan oleh karena domba lokal dalam penelitian yang dilakukan oleh Supratman, dkk menggunakan domba lokal jantan yang berbeda dengan kajian yang dilaksanakan di UPT PT HMT Jember yang menggunakan domba sapudi betina sebagai bahan kajian.

Tabel 8. FCR Fase Umur 3 - 6 Bulan

$\begin{array}{lcc}\text { Fase Umur } & \text { Fase Umur } & \text { Fase Umur } \\ (3-6 \text { Bulan }) & (6-12 \text { Bulan }) & (>12 \text { Bulan })\end{array}$

\begin{tabular}{cccccc}
\hline $\begin{array}{c}\text { No. Tatto } \\
\text { Domba }\end{array}$ & $\begin{array}{c}\text { Konversi } \\
\text { Pakan }\end{array}$ & $\begin{array}{c}\text { No. Tatto } \\
\text { Domba }\end{array}$ & $\begin{array}{c}\text { Konversi } \\
\text { Pakan }\end{array}$ & $\begin{array}{c}\text { No. Tatto } \\
\text { Domba }\end{array}$ & $\begin{array}{c}\text { Konversi } \\
\text { Pakan }\end{array}$ \\
\hline 658 & 11,86 & 459 & 9,73 & 545 & 10,60 \\
346 & 14,33 & 007 & 16,10 & 501 & 8,89 \\
518 & 11,86 & 357 & 14,15 & 551 & 8,22 \\
631 & 9,05 & 584 & 9,73 & 558 & 7,25 \\
608 & 11,86 & 605 & 16,10 & 335 & 8,89 \\
BN1 & 8,00 & 491 & 7,53 & 100 & 12,81 \\
671 & 11,86 & 411 & 12,29 & 345 & 11,48 \\
528 & 14,33 & 010 & 8,98 & 553 & 16,70 \\
BN2 & 18,11 & 606 & 24,58 & 002 & 9,67 \\
589 & 24,57 & 585 & 7,53 & 350 & 9,67 \\
\hline Rerata & 13,58 & \multicolumn{5}{|c}{12,67} & & 10,42 \\
\hline
\end{tabular}

Sumber: Data primer (2020)

Perhitungan konversi pakan domba sapudi fase umur $>12$ bulan diperoleh hasil dengan rerata yakni 10,42 (Tabel 8). Hal ini dapat di artikan bahwa untuk menghasilkan $1 \mathrm{~kg}$ bobot badan, maka diperlukan pakan sebanyak 10,42 kg. Penelitian yang dilakukan oleh Setiadi, et al., (2016) menerangkan bahwa domba betina lokal umur 10 - 12 bulan dengan perlakuan pakan memiliki rentang hasil konversi pakan dengan rerata 10,6 - 13,0 yang berarti hasil dari penelitian tersebut terbilang memiliki kesamaan dengan hasil kajian yang dilaksanakan di UPT PT dan HMT Jember.

Hasil perhitungan konversi pakan domba Sapudi berbagai umur pada kajian ini diperoleh hasil bahwa, konversi pakan paling efisien didapat oleh domba sapudi pada fase umur $>12$ bulan dengan rerata yakni 10,42, kemudian disusul oleh domba sapudi fase umur 6 - 12 bulan dengan rerata konversi pakan senilai 12,67 , dan konversi pakan paling tidak efisien didapat oleh domba sapudi pada fase umur 3 - 6 bulan dengan hasil rerata 13,58. Semakin kecil nilai koversi pakan maka akan semakin efisien juga pemberian pakannya. Konversi pakan yang tidak efisien disebabkan oleh tingginya pakan yang dikonsumsi oleh ternak, yang berbanding terbalik dengan rendahnya $\mathrm{PBBH}$ yang dihasilkan.

\section{Estimasi Biaya Pakan}

Feed cost per gain (fc/g) adalah besarnya biaya pakan yang diperlukan ternak untuk menghasilkan $1 \mathrm{~kg}$ gain (Handayanta, et al., 2017) Feed cost per gain ini dihitung berdasarkan pada harga pakan yang dikeluarkan setiap hari oleh UPT PT dan HMT Jember dibagi dengan rerata pertambahan bobot badan yang dihasilkan. 
Aji et al.

ANIMPRO: Conference of Applied Animal Science Proceeding Series

Tabel 11. Feed Cost Per Gain

Feed Cost Per Gain

\begin{tabular}{ccc}
\hline $\begin{array}{c}3-6 \text { Bulan } \\
\text { (Rupiah/ekor) }\end{array}$ & $\begin{array}{c}6-12 \text { Bulan } \\
\text { (Rupiah/ekor) }\end{array}$ & $\begin{array}{c}\text { > 12 Bulan } \\
\text { (Rupiah/ekor) }\end{array}$ \\
\hline Rp 14.036 & Rp 13.190 & Rp 11.804 \\
\hline
\end{tabular}

Sumber: Data primer (2020)

Hasil studi menunjukkan bahwa rerata nilai feed cost per gain (fc/g) adalah Rp14.036 untuk fase umur 3 - 6 bulan yang berarti, untuk menghasilkan $1 \mathrm{~kg}$ bobot badan diperlukan biaya pakan sebesar Rp 14.036. Fc/gain Rp 13.190 untuk fase umur 6 - 12 bulan yang berarti untuk menghasilkan $1 \mathrm{~kg}$ bobot badan diperlukan biaya pakan sebesar $\mathrm{Rp} 13.190$, dan $\mathrm{Rp} 11.804$ untuk fase umur $>12$ bulan yang berarti, untuk menghasilkan $1 \mathrm{~kg}$ bobot badan diperlukan biaya pakan sebesar Rp 11.804. Nilai fc/g ini cukup tinggi disebabkan oleh nilai efisiensi pakan yang rendah, sehingga walaupun domba mengkonsumsi BK dalam jumlah yang mendekati standar, akan tetapi domba tersebut tidak bisa memberikan $\mathrm{PBBH}$ yang baik.

Tabel 12. Income Over Feed Cost

\begin{tabular}{cccc}
\hline Fase Umur & Income PBBH/ekor (Rupiah) & $\begin{array}{c}\text { Feed Cost/ekor } \\
\text { (Rupiah) }\end{array}$ & $\begin{array}{c}\text { Income Over } \\
\text { Feed Cost/ekor } \\
\text { (Rupiah) }\end{array}$ \\
\hline 3 - 6 Bulan & Rp 37.000,00 x 0,028 kg = Rp 1.036 & Rp 393 & Rp 643 \\
6 - 12 Bulan & Rp 37.000,00 x 0,042 kg = Rp 1.554 & Rp 554 & Rp 1.000 \\
$>12$ Bulan & Rp 37.000,00 x 0,056 kg = Rp 2.072 & Rp 661 & Rp 1.411 \\
\hline Sumber: Data primer (2020) & &
\end{tabular}

Perhitungan Income Over Feed Cost (IOFC) atau pendapatan atas biaya pakan dilakukan untuk mengetahui nilai ekonomis pakan terhadap pendapatan di UPT PT dan HMT Jember. Income over feed cost dihitung dengan cara mengalikan rerata PBBH dengan asumsi harga jual domba bulan Agustus 2021, yaitu Rp 37.000,00/kg bobot hidup untuk kemudian dikurangi dengan biaya pakan (Rp/ekor). Nilai IOFC yang tinggi diperoleh dari pemilihan bahan - bahan pakan penyusun ransum haruslah semurah mungkin (Sodikin, et al., 2016).

Berdasarkan perhitungan Tabel 12 diperoleh nilai IOFC tertinggi setelah di kurangi biaya Feed Cost adalah pada domba fase umur $>12$ bulan yakni sebesar Rp 1.411/ekor yang berarti usaha peternakan domba ini mendapatkan keuntungan sebesar Rp 1.411/ekor, IOFC sedang didapat oleh domba pada fase umur 6 - 12 bulan sebesar Rp 1.000/ekor yang berarti usaha peternakan domba ini mendapatkan keuntungan sebesar Rp 1.000/ekor dan IOFC terkecil didapat oleh domba sapudi fase umur 3 - 6 bulan yakni sebesar Rp634/ekor yang berarti usaha peternakan domba ini mendapatkan keuntungan sebesar Rp 634/ekor saja. Nilai positif ini menunjukkan bahwa usaha yang dijalankan mengalami keuntungan walaupun kecil. Keuntungan yang kecil ini disebabkan oleh nilai income yang berasal dari PBBH sangat rendah. Nilai IOFC ransum dipengaruhi oleh besarnya pendapatan dan besarnya biaya konsumsi ransum. Nilai IOFC ransum yang semakin tinggi menunjukkan semakin baiknya nilai ekonomis ransum yang dikonsumsi domba.

\section{KESIMPULAN}

Performa PBBH terbaik dihasilkan oleh domba sapudi fase umur $>12$ bulan dengan rerata hasil $55,71 \mathrm{~g} / \mathrm{ekor} / \mathrm{hari}$, kemudian diikuti oleh domba sapudi fase umur 6 - 12 bulan dengan rerata 41,90 g/ekor/hari, dan PBBH paling rendah diperoleh oleh domba sapudi fase umur 3 - 6 bulan yakni sebesar 27,62 g/ekor/hari. Pemeliharaan domba sapudi dalam jangka waktu pendek akan jauh lebih menguntungkan apabila peternak menggunakan domba sapudi betina pada fase umur di atas 12 bulan, karena pada fase umur tersebut, pertumbuhan domba Sapudi telah berfokus 
Aji et al.

ANIMPRO: Conference of Applied Animal Science Proceeding Series

kepada pertambahan bobot badannya saja, sehingga pakan yang dikonsumsi akan jauh lebih efisien

\section{DAFTAR PUSTAKA}

Bagiarta, I. W., Mudita, I. M., Roni, G. K., \& Lindawati, S. A. (2017). Dimensi Tubuh Sapi Bali Di Unit Pelaksana Teknis Pembibitan Sapi Bali Sobangan, Badung. Journal Of Tropical Animal Science, 5(1), 181-188.

Braymana, B. S., Sembiring, I., \& Budi, U. (2014). Pemanfaatan Sisa Panen Tanaman Pisang Sebagai Pengganti Rumput Dalam Pakan Komplit Berbentuk Pelet Terhadap Performans Domba Lokal Jantan Lepas Sapih. Jurnal Peternakan Integratif, 2(2), 102-111.

Handayanta, E., Lutojo, \& Nurdiati, K. (2017). Efisiensi Produksi Sapi Potong Pada Peternakan Rakyat Pada Musim Kemarau Di Daerah Pertanian Lahan Kering Kabupaten Gunungkidul. Caraka Tani: Journal Of Sustainable Agriculture, 32(1), 49-54. Https://Doi.Org/10.20961/Carakatani.V32i1.15928

Jaya, Y., Muhtarudin, Adhianto, K., \& Erwanto. (2020). Pengaruh Penggunaan Fermentasi Dan Amoniasi Kulit Singkong Dalam Ransum Terhadap Pertambahan Bobot Tubuh Dan Konversi Pakan Pada Ternak Domba Jantan. Jurnal Riset Dan Inovasi Peternakan (Journal Of Research And Innovation Of Animals), 4(2), 66-70. Https://Doi.Org/10.23960/Jrip.2020.4.2.66-70

Malewa, A. (2009). Penaksiran Bobot Badan Berdasarkan Lingkar Dada Dan Panjang Badan Domba Donggala. Journal Agroland, 16(1), 91-97.

Mentan, R. I. (2012). Penetapan Rumpun Domba Sapudi. Retrieved June 28, 2021, From Keputusan Menteri Pertanian Nomor 2389/Kpts/Lb.430/8/2012 Website: Http://Pustaka.Ditjenpkh.Pertanian.Go.Id/Berita/Komoditas/Domba_Sapudi.Pdf

Mentan, R. I. (2014). Pedoman Pembibitan Kambing Dan Domba Yang Baik. Retrieved June 28, 2021, From Peraturan Menteri Pertanian Republik Indonesia Nomor 102/Permentan/Ot.140/7/2014 Website:

Http://Perundangan.Pertanian.Go.Id/Admin/P_Mentan/Permentan\%20no.102\%20tahun\%202014\% 20pembibitan\%20kambing.Pdf

Metkono, O. A. F., Kardaya, D., \& Sudrajat, D. (2011). Performa Domba Lokal Yang Diberi Ransum Rumput Lapang Dan Ampas Tahu Yang Dipelihara Secara Tradisional. Jurnal Pertanian, 2(2), 8893.

Munir, I. M., \& Kardiyanto, E. (2015). Peningkatan Bobot Badan Domba Lokal Di Provinsi Banten Melalui Penambahan Dedak Dan Rumput. Prosiding Seminar Nasional Teknologi Peternakan Dan Veteriner 2015, 390-396.

Nuningtyas, Y. F. (2014). Pengaruh Penambahan Tepung Bawang Putih (Allium Sativum) Sebagai Aditif Terhadap Penampilan Produksi Ayam Pedaging. Journal Ternak Tropika, 15(1), 21-30.

Nurhayati. (2008). Studi Perbandingan Metode Sampling Antara Simple Random Dengan Stratified Random. Jurnal Basis Data, Ict Research Center Unas, 3(1), 18-32.

Praja, H. M., Nurmeidiansyah, A. A., \& Heriyadi, D. (2020). Rataan Bobot Sapih Dan Pertambahan Bobot Badan Domba Garut Dari Lepas Sapih Hingga Umur 8 Bulan Di Uptd Bpptdk Margawati 2014-2016. Jurnal Produksi Ternak Terapan, 01(01), 8-16. Https://Doi.Org/10.24198/Jptt.V1i1.27644

Purbowati, E., Sutrisno, C. I., Baliarti, E., Budhi, S. P. S., Lestariana, W., Rianto, E., \& Kholidin. (2009). Penampilan Produksi Domba Lokal Jantan Dengan Pakan Komplit Dari Berbagai Limbah Pertanian Dan Agroindustri. Seminar Nasional Kebangkitan Peternakan - Semarang, 130-138.

Rochana, A., Dhalika, T., Ayuningsih, B., Popy Indriani, N. M., Latipudin, D., Winaryanto, S., \& Rahmat, D. (2020). Pengaruh Imbangan Protein Dan Energi Terhadap Efisiensi Penggunaan Ransum Domba Garut Jantan Periode Pertumbuhan. Jurnal Ilmu Ternak Universitas Padjadjaran, 20(1), 69-75. Https://Doi.Org/10.24198/Jit.V20i1.23611

Sampurna, I. P. (2016). Kebutuhan Nutrisi Hewan. Retrieved June 28, 2021, From Https://Simdos.Unud.Ac.Id/Uploads/File_Pendidikan_1_Dir/62d5f41a206162d\%0ad3103b53ec9b4 e614.Pdf

Setiadi, D., Nurachma, S., \& Dhalika, T. (2016). Pengaruh Pemberian Ransum Lengkap Fermentasi Mengandung Kadar Protein Berbeda Terhadap Pertambahan Bobot Badan Dan Konversi Ransum Domba Lokal Betina. Students E-Journal, 5(2). 
Aji et al.

ANIMPRO: Conference of Applied Animal Science Proceeding Series

Sodikin, A., Erwanto, \& Adhianto, K. (2016). Pengaruh Penambahan Multi Nutrient Sauce Pada Ransum Terhadap Pertambahan Bobot Badan Harian Sapi Potong. Jurnal IImiah Peternakan Terpadu, 4(3), 199-203.

Supratman, H., Setiyatwan, H., Budinuryanto, D. C., \& Fitriani, A. (2016). Pengaruh Imbangan Hijauan Dan Konsentrat Pakan Komplit Terhadap Konsumsi, Pertambahan Bobot Badan Dan Konversi Pakan Domba. Jurnal Ilmu Ternak, 16(1), 31-35. Https://Doi.Org/10.24198/Jit.V16i1.9822

Suwignyo, B., Wijaya, U. A., Indriani, R., Kurniawati, A., Widiyono, I., \& Sarmin. (2016). Konsumsi, Kecernaan Nutrien, Perubahan Berat Badan Dan Status Fisiologis Kambing Bligon Jantan Dengan Pembatasan Pakan. Jurnal Sain Veteriner, 34(2), 210-219. Https://Doi.Org/10.22146/Jsv.27560

Zulkarnain, N., Wardoyo, \& Kumala, R. (2018). Pengaruh Pemberian Pakan Silase Batang Pisang (Musa Paradisiaca) Terhadap Pertambahan Bobot Badan Domba Ekor Gemuk. Jurnal Ternak, 9(2), 17-22. 